\title{
ERRATUM
}

\section{Incidence and clinical presentation of acute otitis media in children aged $<6$ years in European medical practices - ERRATUM}

\author{
J. G. LIESE, S. A. SILFVERDAL, C. GIAQUiNTO, A. CARMONA, \\ J. H. LARCOMBE, J. GARCIA-SICILIA, A. FUAT, M. GARCES-SANCHEZ, \\ M. L. ARROBA BASANTA, E. MUÑOZ HIRALDO, L. CANTARUTTI, \\ W. KROENIGER, J. VOLLMAR, K. HOLL, J. Y. PIRÇON AND \\ M. R. ROSENLUND
}

doi: http://dx.doi.org/10.1017/S0950268813002744. Published by Cambridge University Press, 13 December 2013.

The publisher apologises that the declaration of interest for A. Fuat, E. Muñoz Hiraldo, and L. Cantarutti was omitted from the article (Liese et al. 2013). These authors have no conflict of interest to declare.

\section{REFERENCE}

Liese JG, et al. Incidence and clinical presentation of acute otitis media in children aged <6 years in European medical practices. Epidemiology and Infection. 2013; 142: 1778-1788. doi: http://dx.doi.org/10.1017/S0950268813002744. 